\title{
PULSKI EGZIL RASPARAGANA, KRALJA SARMATSKIH ROKSOLANA
}

Dva nadgrobna natpisa iz Pule svjedoče o boravku u gradu, u 2. stoljeću, roksolanskoga kralja Rasparagana i njegova sina Peregrina. Roksolani su sarmatski narod posvjedočen na ušću Dnjepra i Volge u 2. - 1. stoljeću pr. Kr., koji se tijekom 1. stoljeća pr. Kr. preselio na područje između ušća Dunava i Dnjestra, te je tako došao u doticaj s granicom rimske države. U doba Flavijevaca u više su navrata upadali u Meziju, a za Trajanova Prvog dačkog rata bili su saveznici Dačana. U Drugom dačkom ratu bili su neutralni i za to su od Trajana dobivali godišnju naknadu. Kad je na prijestolje došao Hadrijan, pobunili su se, pa je car pregovarao s njihovim kraljem i ponovo uspostavio mir. Pulski natpisi svjedoče o roksolanskom kralju Rasparaganu, rimskom građaninu ( $P$. Aelius R.), koji je tamo imao sina oženjenog Atijom Procilom. Vrlo je vjerojatno da je Rasparagan bio prvak Roksolana s kojim je Hadrijan pregovarao, ali iz nekog je razloga morao napustiti svoj narod i skrasiti se u Puli, gdje je njegov sin postao punopravni rimski građanin. Epizoda svjedoči o postupcima Rima s nekim barbarskim plemenima uz rimsku granicu, o horizontalnoj i vertikalnoj pokretljivosti rimskih društvenih struktura te o otvorenosti rimskoga društva.

Ključne riječi: antička Istra; antička Pula; Roksolani; Rasparagan.

U lapidariju Arheološkog muzeja Istre u Puli čuvaju se dva sarkofaga, kojih su sačuvane samo prednje strane s natpisima koji spominju sarmatskog kralja Rasparagana.

1. P(ublio) Aelio Rasparagano / regi Roxo[la]noru[m] / [u(xor)] v(iva) [f(ecit)]

2. P(ublius) Aelius Peregrinus reg[is] / Sarmatarum Rasparagani / f(ilius) v(ivus) f(ecit) sibi et Attiae Q(uinti) f(iliae) Procillae, lib(ertis) l[iber]/tabusq(ue) posterisq(ue) eorum ${ }^{2}$

1 CIL 5, 32; ILS 852; Inscr. It., 10, 1, 153; EDR136173. Vis. 55 cm, duž. 205 cm, deb. 13 cm. CIL i ILS u trećem retku imaju $V$. V. F i objašnjenje Vivus vivo fecit.

2 CIL 5, 33; ILS 853; Inscr. It., 10, 1, 154; EDR136176. Vis. 55 cm, duž. 205 cm, deb. 15 cm. 


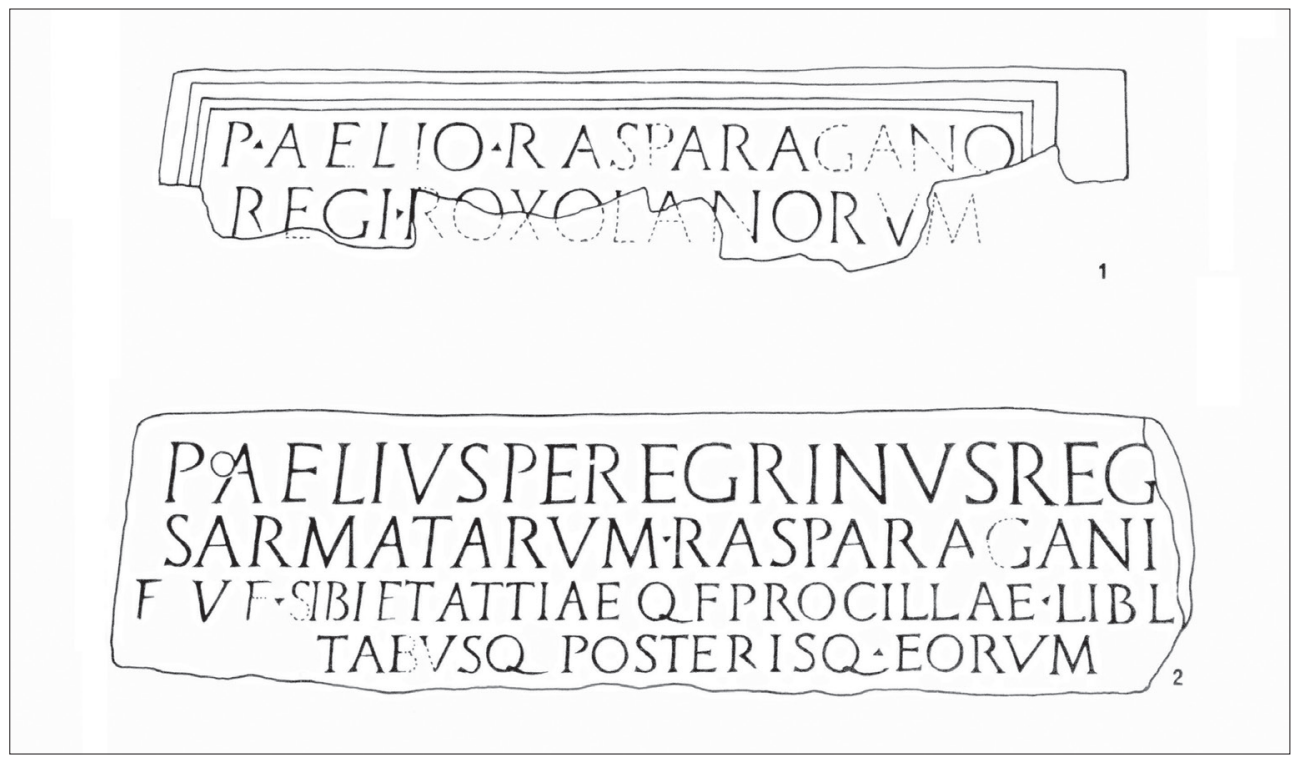

Slika 1 - Natpisi Publija Elija Rasparagana i njegova sina Publija Elija Peregrina (Vaday 1977)

Prvi je natpis nakon nalaza u 17. stoljeću imao burnu suvremenu povijest: navodno je pronađen na otočiću Uljaniku (Scoglio Olivi) u Pulskom zaljevu, ${ }^{3}$ ali je prenesen u Kopar, gdje je (kako je bio cjelovito sačuvan) služio kao spremnik za maslinovo ulje, odnosno vodu. ${ }^{4}$ Tamo ga je vidio i Theodor Mommsen kad je obilazio istarsko i tršćansko područje u potrazi za rimskim natpisima koje je objavio u znamenitoj zbirci Corpus Inscriptionum Latinarum (CIL). ${ }^{5}$ Godine 1866. Pietro Kandler prenio ga je u Trst, a dvije godine kasnije dao ga je prenijeti $\mathrm{u}$ Pulu, gdje je izvorno i pronađen. Danas se čuva u lapidariju Arheološkog muzeja Istre u Puli, u sedam ulomaka: ${ }^{6}$ nedostaju dijelovi drugog retka te veći dio trećeg

\footnotetext{
3 Weisshäupl 1901, 203.

4 Forlati Tamaro 1947, 83 u komentaru natpisa (Inscr. It., 10, 1, 153, str. 83) navodi da je to razvidno iz pisma koje je Matteo Madrucci u Bujama napisao 7. srpnja 1676. Sertoriju Orsatu u Padovu. Brojni ga drugi rukopisni i tiskani izvori u 17. i 18. stoljeću (Prospero Petronio, Vincenzo Scussa, Gianrinaldo Carli) spominju na više mjesta u Kopru i njegovoj okolici.. je Mommsen vidio cijeloga,i donje po velikiveralni tekst trećeg retka (V.V.F), a u pulski je Muzej došao fragmentiran, ške, d

5 Mommsen ga je vidio u Črnom Kalu kraj Kopra dok je bio cjelovit i služio kao spremnik za vodu: Forlati Tamaro 1947, 83.

6 Nije jasno kad je sarkofag razbijen, jer ga je Mommsen vidio cijeloga i zabilježio integralni tekst trećeg retka (V.V.F), a u pulski su Muzej došli samo ulomci prednje strane s natpisom, kojemu su nedostajali dijelovi donje površine.
} 
retka, od kojeg je samo središnje v(iva) danas sačuvano. Donji rub sarkofaga nije sačuvan, dok je duž preostala tri ruba sačuvana jednostavna profilacija natpisnog polja.

Drugi je natpis cjelovit, iako prelomljen $\mathrm{u}$ četiri dijela, a na desnom rubu nedostaje nekoliko slova u 1. i 3. retku. Kako proizlazi iz dopisivanja Giovannija Carrare, Pietra Kandlera i Domenica Bronzina, pronađen je sredinom 19. stoljeća na otočiću Uljaniku u pulskoj luci, ${ }^{7}$ te je prenesen u tadašnji lapidarij u Augustovu hramu, odakle je 1920-ih premješten, zajedno sa svim drugim lapidama (pa i prvim natpisom), u tada novoustrojeni Istarski kraljevski muzej (Regio Museo dell'Istria), danas Arheološki muzej Istre. Oba su se natpisa do preuređenja muzeja, koje je započelo 2015. godine, nalazila u lapidariju u prizemlju muzejske zgrade.

Već su Kandler i Mommsen prepoznali roksolansko etničko ime i povezali ga s kratkim spomenom u Hadrijanovu životopisu iz Carske povijesti (Historia Augusta): Audito dein tumultu Sarmatarum et Roxolanorum praemissis exercitibus Moesiam petiit. Marcium Turbonem post Mauretaniam praefecturae infulis ornatum Pannoniae Daciaeque ad tempus praefecit. Cum rege Roxolanorum, qui de inminutis stipendiis querebatur, cognito negotio pacem composuit. ${ }^{8}$ Kontekst je jasan i zbog gentilicija koji nose Rasparagan i njegov sin Peregrin, a koji upućuje na Hadrijana (Publius Aelius Hadrianus) kao davatelja rimskog građanstva. Pisac Hadrijanova životopisa ne spominje ime kralja, ali se vjerojatno radi upravo o Rasparaganu, to pretpostavljaju i svi suvremeni povjesničari koji su se bavili Roksolanima i Sarmatima u 1. i 2. stoljeću. Osebujni stil pisanja autora Hadrijanova životopisa sažima zajedno Roksolane i Sarmate, ali treba ih jasno diferencirati; radilo se o dva naroda koji možda i nisu živjeli u neposrednom susjedstvu. Roksolani su u to doba živjeli oko ušća Dunava, a Trajan ih je primirio sklapanjem savezništva uz plaćanje određene svote novca, dok se za Sarmate smatra da pod tim imenom, u ovom kontekstu, ustvari treba vidjeti Jazige, koji su živjeli između Tise i Dunava. Ime Sarmata obuhvaćalo bi niz zajednica, među kojima Jazige i Roksolane.

Strabon Amasejac (1. stoljeće pr. Kr. - poč. 1. stoljeća po Kr.) u Geografiji spominje Roksolane na dva mjesta. Najprije u uvodnom pregledu geografskih krajnosti piše da su Roksolani od svih poznatih Skita najudaljeniji, da žive onkraj Boristena (Dnjepra), da južnije od njih žive Sarmati oko Maeotskog

\footnotetext{
Iz te činjenice potječe i pretpostavka o mjestu nalaza prvog natpisa, jer je njihova kontekstualnost očevidna.

8 HA, Hadr., 6, 6-8: „Zatim je saznao za nemir Sarmata i Roksolana, pa je na njih poslao vojske za kojima je krenuo u Meziju. Prefekturu Panonije i Dakije privremeno je povjerio Marciju Turbonu, kojem je po njegovu povratku iz Mauretanije dao prefektska odličja. Razmotrio je žalbu roksolanskog kralja zbog smanjenja plaće i sklopio s njima mir." (prijevod Daniel Nečas Hraste).
} 
jezera (Azovsko more), a zemlje sjeverno od Roksolana da su nenastanjene zbog

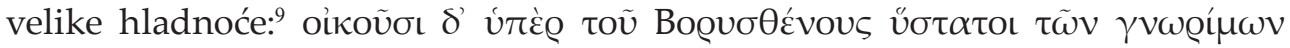

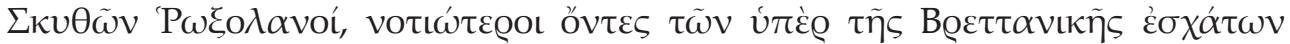

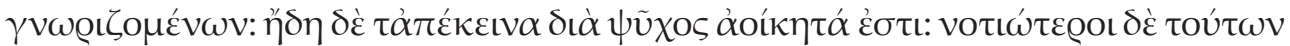

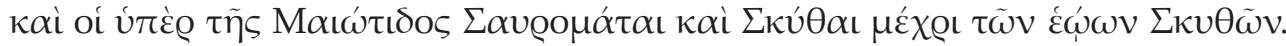
Skiti se u tom kontekstu pojavljuju najprije kao ime šire zajednice naroda kojoj pripadaju i Roksolani, a kasnije i kao zasebni etnički pojam.

Na drugom mjestu, u podrobnijem opisu sjeverne obale Crnoga mora (Pon-

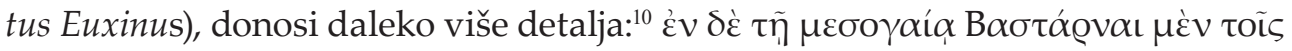

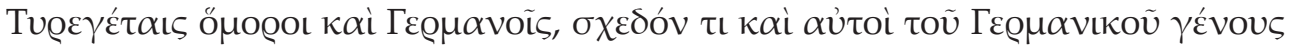

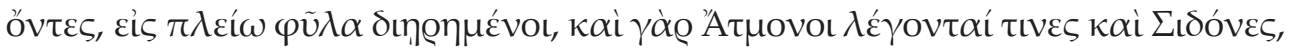

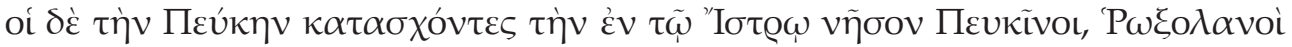

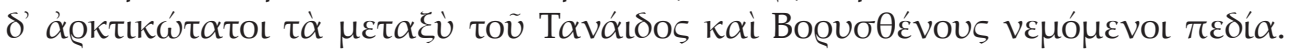
Počevši nabrajanje od germanskih Bastarna, koji su obitavali između ušća Dunava (Ister) i Dnjestra (Tyras), zatim Tiregeta dalje prema istoku, kao najsjevernije navodi upravo Roksolane, koji naseljavaju prostor između Dnjepra (Boristen) i Dona (Tanais). U nekim rukopisima ove Strabonove rečenice ime Roksolana napisano je u oblicima ' $\pi \omega \xi \alpha \nu o$ ó, ' $\pi \omega \xi \alpha \nu$ o i ' $\pi \omega \xi$ o $\alpha$ vó́."

Sudeći prema drugoj rečenici istoga poglavlja, ${ }^{12}$ moglo bi se zaključiti ${ }^{13}$ da su Roksolani činili dio saveza srodnih nomadskih naroda, možda obuhvaćenih zajedničkim imenom Sarmata, ${ }_{14}^{14}$ a koji je obuhvaćao Jazige, Urge, Roksolane i Kraljevske Sarmate (ili Skite?). ${ }^{15}$ Pritom bi ovi potonji predstavljali jezgru plemenskog saveza, elitu oko koje se okupljaju srodne manje zajednice jačajući na taj način svoj položaj na širem prostoru sjevernog crnomorskog priobalja u 1. stoljeću pr. Kr. IStrabon spominje njihov pretežito nomadski karakter, iako ỏ $\lambda \dot{\gamma} \gamma o$

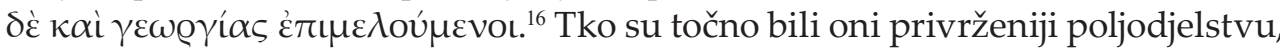
ne možemo znati, ali cijeli je veliki prostor od ušća Dunava do Azovskog mora (danas južna Ukrajina) svojim izrazito ravničarskim karakteristikama pružao mogućnosti kako za nomadizam, tako i za sjedilačko poljodjelstvo.

\footnotetext{
9 Strabo 2, 5, 7, 13.

10 Strabo 7, 3, 17, 4 .

11 Usp. izdanje A. Meineke, Leipzig: Teubner, 1877.

12 Strabo 7, 3, 17, 3.

13 Harmatta 1970, 12.

14 Plin. NH, 4, 83; 11, 5, 8; Bârcă 2013, 103, 107-108; Bârcă, 2014, 172.

15 Herodot iz naziva Kraljevskim Skitima (4, 20; 4, 22; 4, 56; 4, 57; 4, 59), a Ptolomej Sarmatima (5, 9, 16). Njihovi se podaci razlikuju i zbog velikog vremenskog razmaka između njih.

16 Strabo 7, 3, 17, 3.
} 
Ali Strabon nastavlja donoseći i podatke o Roksolanima u kontekstu njihova ratovanja protiv pontskoga kralja Mitridata VI. Eupatora, koji je, tek što je zasjeo na prijestolje, intervenirao u sukob helenističkog Hersoneza na Kri-

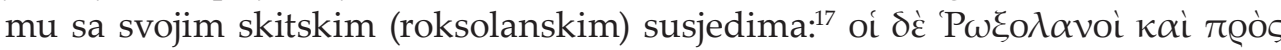

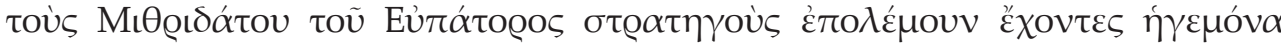

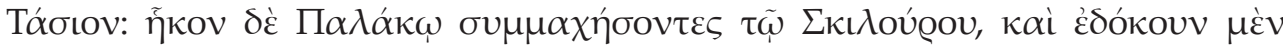

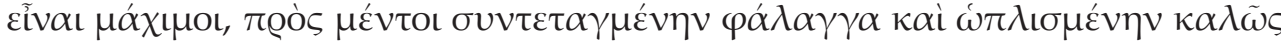

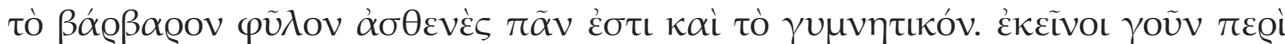

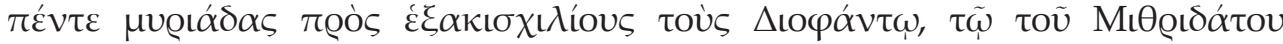

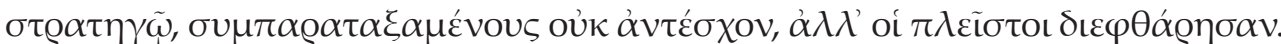
Ukratko, Roksolani su pod vodstvom Tasija došli u pomoć vođama (kraljevima) Skita, Skiluru i njegu sinu Palaku, protiv Hersoneza na Krimu, a ovaj je zatražio Mitridatovu pomoć. Malobrojniji Mitridatovi vojnici pod vodstvom njegova generala Diofanta porazili su brojčano nadmoćniju, ali slabije organiziranu vojsku Roksolana i drugih Sarmata. Diofantova pobjeda zabilježena je na natpisu koji su stanovnici Hersonzsa podigli generalu u čast. ${ }^{18}$

Na ovom mjestu Strabon opisuje vojničku opremu Roksolana, koji koriste kacige i oklope od neštavljene volovske kože, štitove od pruća, a naoružani su

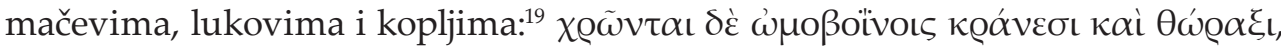

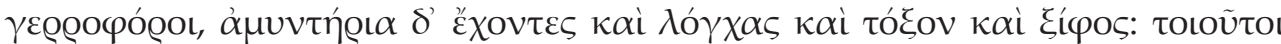

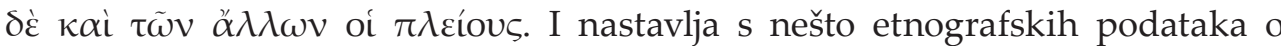
nomadskim nastambama (šatorima) i načinu života oko Azovskog mora: ${ }^{20} \tau \tilde{\omega} v$

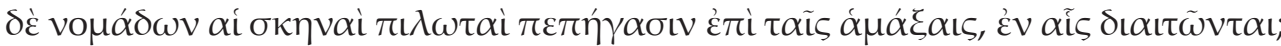

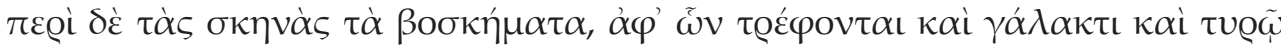

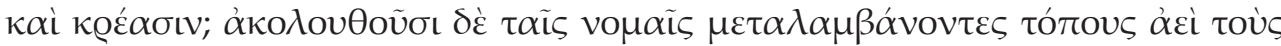

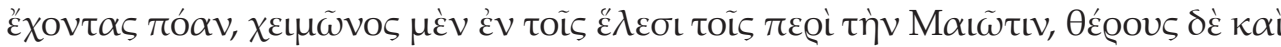

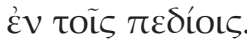

Pitanje Strabonovih izvora za ove i druge podatke za sjeverno crnomorsko primorje nemoguće je razriješiti, jer nema dovoljno elemenata, ali uobičajene se pretpostavke svode na Artemidora za zemljopisne elemente, Posidonija za etnografske i Hipsikrata za povijesne podatke. ${ }^{21}$

Međutim, pod pritiskom silnih manjih i većih migracija s istoka, dijelovi skitske (sarmatske) konfederacije tijekom 1. stoljeća pr. Kr. krenuli su prema zapadu,

\footnotetext{
17 Strabo 7, 3, 17, 6-7.

Syll. inscr. graecarum. ${ }^{3}$, 709. Podrobnije o ovim događajima Milićević Bradač 2004, 160-161.

9 Strabo 7, 3, 8

20 Strabo 7, 3, 9

21 Argumentiranu raspravu o izvorima v. u: Harmatta 1970, 14-15; v. i Rostovtzeff 1931, I, 92-93.
} 
u organiziranim skupinama kao cjelovite zajednice, ratnici, žene i djeca na čelu s plemenskim prvacima. Polunomadski život na sjevernim obalama Crnog mora zamijenili su istim takvim životom zapadnije, pa tako na prijelazu iz 1. stoljeća. pr. Kr. u 1. stoljeće po Kr. Jazige nalazimo u Mađarskoj, a druge sastavnice sarmatske skupine naroda oko dunavskog ušća. ${ }^{22}$ Između Jaziga (između Tise i Dunava) i Roksolana (između Karpata i dunavskog ušća) ispriječili su se Dačani, trako-frigijski narod koji se u Transilvaniji i na obje obale donjeg toka Dunava formirao tijekom posljednjih stoljeća pr. Kr., a vrlo su srodni i Getima (trakogetska skupina). ${ }^{23} \mathrm{U}$ 1. stoljeća pr. Kr. oblikovali su čvrst plemenski savez koji je vrhunac dosegao za „kralja“ Burebiste (vladao 88. - 44. godine pr. Kr.) i koji se s manjim oscilacijama održao do vremena Trajanovih ratova protiv Dačana. A homogenost dačkoga kulturno-političkoga prostora onemogućavala je ostvarenje izravnih dodira sarmatskih Jaziga i Roksolana, zapadno i istočno od Karpata.

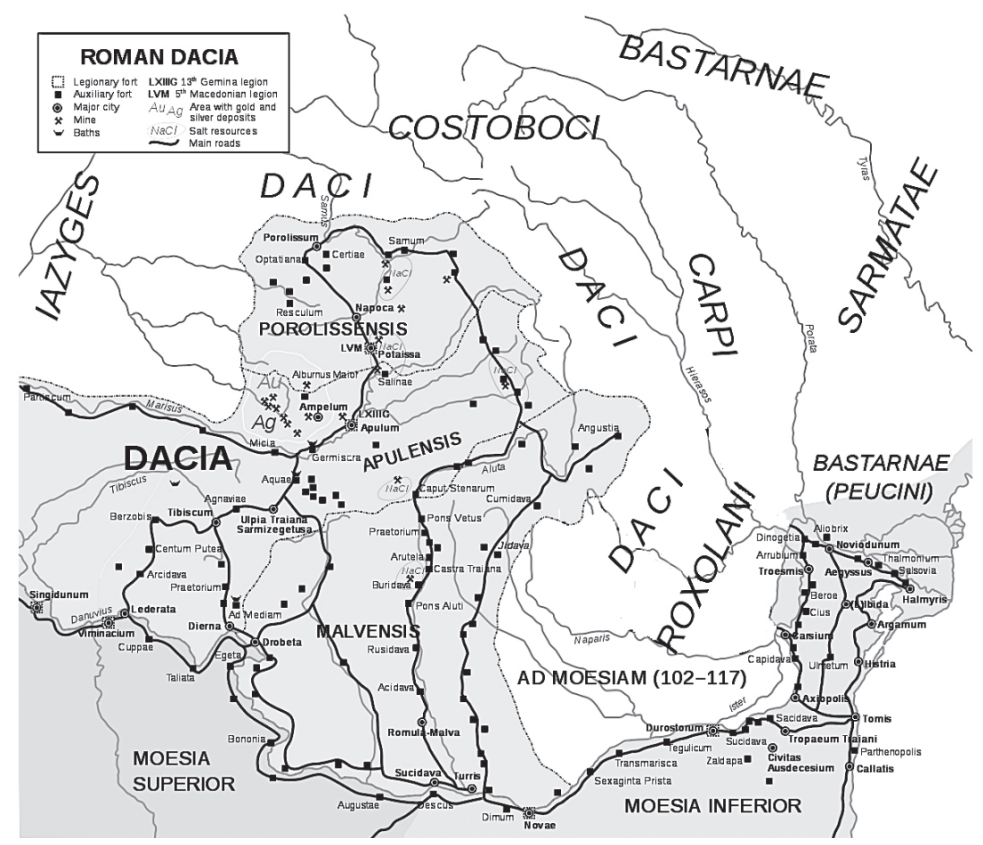

Slika 2 - Rimska provincija Dacija, prerađeno prema: Nacu, Andrei, "Map of Roman Dacia", https://www.ancient.eu/image/331/. Ancient History Encyclopedia. Last modified April 26, 2012 (preuzeto 4. 4. 2020.)

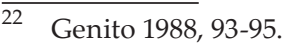

23 Mócsy 1974, 4 i 27; Bennett 1997, 87.
} 
Kad su Jazigi i Roksolani krenuli prema zapadu, na ušću Dona (Tanais, ranija postojbina Roksolana) našli su se Alani, koji su svojim pritiskom vjerojatno i uzrokovali pomicanja sarmatskih naroda prema zapadu. Oni su Strabonu još bili izvan vidokruga, pa ih ne spominje u kontekstu zemljopisa sjevernog crnomorskog primorja. Alani, koji su poput Jaziga, Skita, Roksolana, Sarmata pripadali indoiranskoj etničkoj skupini, iz svoje nove postojbine učestalo su upadali na kavkasko područje i u Partiju, tako da su znatno pridonosili nestabilnosti vanjskog ruba rimskih istočnih provincija. Etimologiju etničkog imena Roksolana neki filolozi povezuju s kombinacijom ruxh-ili rukh-alani (,,svijetli Alani“), a to opet s ruskim entičkim imenom (rus-alani). ${ }^{24}$

U 1. stoljeću pr. Kr. Roksolani su pod pritiskom istočnijih naroda krenuli iz svoje najranije zabilježene domovine, između Volge, Dona i Dnjepra, prema Krimu i ušću Dunava. ${ }^{25}$ Već su sredinom 1. stoljeća po Kr. započeli povremeno prodirati preko Dunava na područje Mezije, a u tzv. "godini četiriju careva“ jedan su takav pohod 9.000 roksolanskih ratnika zaustavile rimske legije i pomoćne postrojbe pod zapovjedništvom namjesnika Mezije. ${ }^{26}$ Tacit opisuje njihov način ratovanja, ${ }^{27}$ pri čemu se čudi naoružanju i opremi: nosili su duge mačeve koje su držali objema rukama, a tijelo i konje štitili su oklopom od kože s prišivenim željeznim pločama (cataphracta), što je prikazano i na reljefu s Trajanova stupa (scena 37). ${ }^{28}$

Poraz 69. godine Roksolani su osvetili 92., kad su uništili 21. legiju (Legio XXI Rapax), ${ }^{29}$ no ubrzo nakon toga Trajan je organizirao pohod protiv Dačana, pa su i Roksolani došli u pogibelj. Na početku Trajanova rata za osvajanje Dacije Roksolani su mu se isprva odupirali, ali su već u prvom pohodu rimske vojske bili poraženi 101. - 102. godine ${ }^{30}$. Potom su u drugom pohodu 105. - 106. ostali neutralni, te su tako izbjegli podjarmljivanje, ${ }^{31}$ ali su granice nove rimske provincije došle nadomak njihova etničkog područja, lijeve obale Dunava kod ušća rijeke u Crno more. Moguće je da je cijena njihove neutralnosti bila plaćanje stipendija (stipendium), ${ }^{32}$ naknade koja će ubrzo dovesti do sljedeće eskalacije. Rimska provincija Dacija, osnovana 106. godine, nadomjestila je dačko „kraljevstvo“ u

\footnotetext{
24 Vernadsky 1959.

25 Ryle 1987, 93.

26 Wilkes 1996, 558; Bârcă 2013, 114; Bârcă 2014, 180-181.

27 Tac., Hist., 1, 79.

28 Wilkes 1983, Pl. II, Pl. III (p. 272); Ryle 1987, 94.

29 Bennett 1997, 33.

30 Bârcă 2014, 182.

31 Bârcă 2013, 117.

32 Bârcă 2013, 117
} 
razdvajanju Jaziga i Roksolana, a rimska je vojska sada nadgledala oba „džepa“: Jazige iz Dacije i Panonije, a Roksolane iz Dacije i Donje Mezije. Prema potonjima je uspostavljena mreža utvrda na donjem toku Dunava, od ušća Olta (Alutus) do dunavskog ušća, s tri veća legijska logora: Novae (Svištov u Bugarskoj), Durostorum (Silistra u Bugarskoj), Troesmis (kraj mjesta Igliţa-Turcoaia u Rumunjskoj) i nizom utvrda pomoćnih postrojbi.

Kad je poslije Trajanove smrti Hadrijan ustoličen za cara, sredinom 117. godine, već je imao iskustva s Dačanima i Jazigima, bio je s Trajanom u Prvom dačkom ratu i potom imenovan namjesnikom Donje Panonije. ${ }^{33}$ Sarmati (Jazigi) i Roksolani pobunili su se ubrzo nakon što se proširila vijest da je car Trajan umro. Kad je saznao za nemire u području donjeg toka Dunava, krajem iste godine, Hadrijan se nalazio u Antiohiji. ${ }^{34}$ Prema tekstu Hadrijanova životopisa u Carskoj povijesti, ${ }^{35}$ car je protiv njih poslao vojsku, te je i sam za njom preko Bitinije prispio u Meziju. Marciju Turbonu, koji je prije toga službovao u Mauretaniji, privremeno je dodijelio prefekturu Panonije i Dacije, a time i vojno zapovjedništvo u toj kriznoj situaciji. Razlog nemira bilo je smanjenje naknade (stipendium) koju je Trajan pristao isplaćivati im u zamjenu za mir. Hadrijan je osobno s njima stupio u pregovore, razmotrio je njihovu žalbu te ponovo s njima sklopio mir. Uvjeti tog sporazuma nisu poznati, ali neki autori pretpostavljaju da je Hadrijan čak pristao povući rimsku vojsku iz područja istočnih obronaka Karpata i lijeve obale ušća Dunava. ${ }^{36}$ To nije potkrijepljeno pisanim izvorima već samo arheološkim podacima, pa pretpostavku valja uzeti s rezervom: povlačenje s obronaka Karpata znatno bi oslabilo sigurnost Dacije, a granica s legijskim pomoćnim logorima na Dunavu i tako je bila uspostavljena.

Prema jednom mogućem tumačenju, za roksolanskog je prvaka („kralja“) sporazum imao dodanu pogodnost, jer je Hadrijan roksolanskoga kralja proglasio „prijateljem rimskog naroda“ (amicus populi Romani) ${ }^{37}$ i dodijelio mu rimsko građansko pravo, kao znak zahvalnosti za sporazum za koji je Hadrijan vjerovao da osigurava mir na dunavskoj granici u području riječnog ušća. Gotovo svi znanstvenici koji su o tome pisali suglasni su da bi to mogao biti upravo Rasparagan s pulskog natpisa. ${ }^{38}$ Sličan je slučaj poznat s natpisa u Rimu, ${ }^{39}$ koji

\footnotetext{
Birley 2000, 133.

34 Diehl 1971, 1195-1197; Bârcă 2013, 118; Bârcă 2014, 183.

35 HA 6, 6-8, v. bilj. 7.

36 Karavas 2001, 151-153.

37 Bârcă 2011, 65.

38 Bârcă 2013, 118; Bârcă 2014, 183-184.

39

CIL 6, $1801=$ ILS 854
} 
spominje kralja Kostoboka (Pieporus rex Costobocensis), koji je također preminuo u Rimu, gdje su mu supruga i dva unuka dali izraditi nadgrobni natpis na latinskome jeziku..$^{40}$ Radi se o „kralju“ sarmatskog naroda koji je živio sjeverno od rimske Dacije, no nije poznato kako je on dospio u Rim. Pet imena koja se spominju u natpisu (Piepor, njegova supruga Sia, kći Tiata, njihovi unuci Natopor i Drigisa) nemaju nikakve druge elemente koji bi ukazivali na to da su imali rimsko građanstvo.

Nije poznato koliko se dugo rimsko-roksolanski sporazum poštovao, ali činjenica da Rasparaganovo ime nalazimo u Puli na dva nadgrobna natpisa mogla bi značiti da su kralja s obitelji njegovi sunarodnjaci u nekom trenutku poslije 118. godine prisilili da napusti svoj položaj, te se on sklonio na području rimske države. Kao rimski građanin (ako je zaista već imao rimsko građanstvo) na to je imao pravo, iako je to u svakom pogledu predstavljalo izbjeglištvo, preseljenje $u$ drugu kulturu. ${ }^{41}$ Rumunjski znanstvenici pretpostavljaju da je to moglo biti već na početku vladavine cara Antonina Pija (138. godine), ${ }^{42} \mathrm{kad}$ se mogao ponoviti scenarij iz 118. godine: da bi od novoga cara ishodili produženje sporazuma, pa možda i bolje uvjete, Roksolani su se ponovo pobunili, ali kako je Rasparagan bio jamac postojećeg sporazuma, iz svoje su ga zajednice protjerali. U tom bi slučaju Rasparagan već kao kralj u svojoj postojbini imao građansko pravo, što ne smatramo vjerojatnim, pa smo bliži mišljenju da se to dogodilo vrlo brzo poslije 118. godine.

Rimska carska historiografija poznaje i druge primjere prihvaćanja barbarskih prvaka koji su zbog prorimskog stava u svojim zajednicama bili odbačeni. To su Marobod (Maroboduus), kralj dunavskih Sveva (Suebi):43 Maroboduo undique deserto non aliud subsidium quam misericordia Cesaris fuit, kojemu je Tiberije utočište pružio u Ravenni; a odmah zatim i njegov suparnik Katuald: ${ }^{44} \mathrm{Idem} \mathrm{Ca}$ tualdae casus neque aliud perfugium, koji je poslan u Forum Julium (Frejus). Slična, ali opet drukčija, bila je sudbina Vanija, također svevskog kralja dva desetljeća kasnije. On se pod zaštitu cara Klaudija stavio zajedno sa svojim pristalicama: ${ }^{45}$ ceterum ad classem in Danuvio opperientem perfugit; secuti mox clientes et acceptis agris in pannonia locati sunt. On nije udaljen iz svoje postojbine u neki udaljeni

\footnotetext{
40 Opreanu 2011, 125-126.

41 Wilkes 2000, 583: ne navodeći kraljevo ime.

42 Bârcă 2014, 184, navodi djelo rumunjskog povjesničara: Constantin C. Petolescu, Dacia un mileniu de istorie, București 2010, 307.

43 Tac. 2, 62-63.

44 Ibid.

45 Tac. $12,30$.
} 
grad u Italiji ili susjednim provincijama samo s najbližom pratnjom već je s pristalicama naseljen u provinciji koja graniči s njegovim bivšim područjem (koje je, uzgred, i dalje ostalo Rimu prijateljski nastrojeno). Vidimo dakle da je Rim, $\mathrm{kad} \mathrm{mu}$ je to bilo u interesu, bio vjeran stranim vladarima uz svoju granicu, nastojeći održati njihovo prijateljstvo, ali i štiteći ih u slučaju potrebe. ${ }^{46}$

To je očito bio slučaj i s Rasparaganom, iako pisani izvori donekle otvaraju mogućnosti za određena nagađanja. Ponajprije valja nam razmotriti pitanje zašto su Rimljani plaćali Roksolanima stipendium. Riječ označava kako vojničku godišnju plaću, tako u drugom značenju i ratnu odštetu koju pobijeđeni plaća pobjedniku. Ovo potonje na prvi je pogled neodrživo, jer je Trajan u Prvom dačkom ratu 101. - 102. godine Roksolane, koji su ratovali na strani Dačana, porazio, pa im nije mogao biti dužan odštetu ${ }^{47}$ ali tumačenje izvora dopušta mogućnost da su u Drugom dačkom ratu 105. - 106. godine ostali neutralnima. ${ }^{48}$ Možda se u tome krije rješenje, ako je Trajan pristao plaćati Roksolanima stipendium kao naknadu za neutralnost. Također valja primijetiti da su u oba dačka rata Rimljani privremeno zaposjeli teritorij Roksolana, Olteniju, Vlašku i dio Moldove, jer su $\mathrm{s}$ istoka napadali Dačane u Karpatima. Nakon oblikovanja provincije pristali su napustiti glavninu toga područja, osim Oltenije, jer je ona bila ključna za obranu jugoistočne granice Dacije. ${ }^{49} \mathrm{Zbog}$ toga, kao i zbog neutralnosti Roksolana u Drugom dačkom ratu, Rimljani su i pristali plaćati stipendium Roksolanima u zamjenu za mir.

Međutim, odnosi Jaziga, Dacije i Roksolana ostavili su otvorenima nekoliko problema, koje se može povezati s nemirima koji su u cijeloj regiji izbili 117. - 118. godine. Jazigi su u Prvom dačkom ratu bili na strani Rimljana, ${ }^{50}$ prvenstveno zato što su im Dačani malo ranije zaposjeli dio područja Banata, a kasnije su bili sve nezadovoljniji jer im Rimljani nisu vratili ta područja, a i zato što su bili odsječeni od Roksolana, a time od transhumantnih ciljeva bliže Crnome moru. Kako se Hadrijan postavio prema Jazigima, iz izvora nije poznato (iako znamo da je tek Marko Aurelije dopustio uspostavljanje prolaza kojim su Jazigi i Roksolani mogli komunicirati) $)^{51}$, ali Historia Augusta izričito kaže da je „razmotrio žalbu roksolanskoga kralja zbog smanjenja stipendija i sklopio s njima mir ${ }^{1 / 52}$.

\footnotetext{
Vaday 1977, 28.

Bârcă 2014, 182.

Bârcă 2013, 117.

Bennett 1997, 167-168.

Bennett 1997, 89.

51 Harmatta 1970, 47.

52

V. bilj. 7.
} 
Ne kaže se da je odustao od smanjenja stipendija i vratio obavezu Rima prema Roksolanima na izvorno dogovoreni iznos već samo da je sklopio s njima mir. To može značiti da je s roksolanskim kraljem (Rasparaganom?) postigao dogovor, kompromis koji nije predstavljao povratak ranijih prava, a to je onda moglo uzrokovati daljnje nezadovoljstvo podanika i elite roksolanskoga društva, koje je naposljetku dovelo do progona ili bijega Rasparagana pod skute rimske države, time i njegova smještaja u Pulu. Osim toga, dogovorom s Rimljanima iznevjerio je savezništvo s Jazigima, s kojima su Roksolani osjećali zajedništvo zbog zajedničkog podrijetla i slične sudbine, ${ }^{53}$ pa je i to moglo utjecati na odluku da napusti svoj zavičaj.

No činjenica da mu je Hadrijan priskrbio građansko pravo pokazuje da je svoju kraljevsku dužnost obavio u interesu rimske politike, koja je na granicama uvijek vrlo pažljivo pratila odnose među narodima koji su živjeli u susjedstvu, jer to je nepobitno utjecalo na sigurnost pograničnog područja, a time i cijele države. Ipak, njegov odlazak morao je zadovoljiti kako Roksolane, tako i Jazige, jer dramatičnih vijesti o novim sukobima u sljedećim desetljećima nema. Vjerujemo da je tek tada, kad je napustio svoje sunarodnjake, dobio rimsko građansko pravo i da se u Puli nastanio sa samo najnužnijom pratnjom, možda suprugom. Rasparaganov natpis ima samo dva sačuvana retka, a od trećeg je sačuvano samo jedno slovo, koje u rekonstrukciji $([u(x o r)] v(i v a)[f(e c i t)])^{54}$ nije posve pouzdano moguće smjestiti u ostatak natpisa, koji je zacijelo postojao, jer ime i titula u dativu podrazumijevaju i ime osobe koja mu je natpis (sarkofag) postavila. Je li to bila supruga ili netko drugi, nije moguće utvrditi. Možda je to bio i sin, koji je dao izraditi drugi sarkofag s natpisom. ${ }^{55}$ Sin mu ne nosi roksolanski kognomen već je Peregrinus, što inače kao opća imenica predstavlja oznaku osobe koja je slobodna, ali nema građansko pravo. Međutim, i njegov gentilicij (kao i očev) jasno ukazuje da su obojica bili rimski građani i vjerojatno treba smatrati da je zaista sam Hadrijan dopustio dodjelu. Jer u građanskopravnoj praksi u prva dva stoljeća po Kr. to je zacijelo bio rijedak slučaj. Za Maroboda i Katualda ne spominje se da su na taj način ",nagrađeni“.

Još nekoliko završnih napomena: iz Peregrinove imenske formule ne može se iščitati je li došao s ocem u Pulu kao dijete ili je pak rođen nakon očeva doseljenja. Ime Rasparaganove supruge možda bi to moglo razriješiti, ali nije sačuvano. Možda je Peregrin ipak bio rođen nakon što je otac već imao građanstvo, možda u Puli (iako ne možemo biti sigurni), zato mu nije nadjenuo neko tradici-

\footnotetext{
53 Vaday 1977, 30-31.

54 CIL 5, 32; ILS 852; Inscr. It., 10, 1, 153; EDR136173.

55

CIL 5, 33; ILS 853; Inscr. It., 10, 1, 154; EDR136176.
} 
onalno roksolansko ime kao kognomen već opću imenicu koja označava stranca. A da nije i ostao "stranac", pokazuje ime supruge, Atije Procile, Kvintove kćeri, koja je očito bila rođena u obitelji s punim građanskim pravom. U natpisu, koji je Peregrin dao izraditi za života, ne spominju se potomci, ali zato je grobno mjesto bilo predviđeno za sve "njihove oslobođenike, oslobođenice i njihove potomke“. Osim što slučaj Rasparagana ocrtava rimski pristup, obrazac osiguravanju i održanju mira u pograničnim pokrajinama, ono malo podataka koje imamo o njegovu sinu zacijelo pridonosi i razumijevanju gospodarskog i životnog uspjeha pojedinca, sina stranca koji je u očima rimske vlasti doduše imao velikih zasluga, no ipak uvijek stranca. Iako je navlas istih takvih slučajeva zacijelo bilo malo, Rasparagan i sin mu Peregrin primjer su koji ilustrira horizontalnu i vertikalnu pokretljivost društvenih struktura, a naposljetku i otvorenost rimskoga društva, njegovu prilagodljivost uvjetima koji su se, naravno, u višestoljetnoj povijesti Carstva mijenjali.

\section{Literatura}

Bârcă 2011 = Vitalie Bârcă, Limes et barbaricum: Nomads of the Steppes at the Danube Frontier of the Roman Empire $\left(1^{\text {st }}\right.$ Century-Beginning of the $2^{\text {nd }}$ Centuriy CE). Historical Outline and Chronological Remark, u: Radu Băjenaru i dr. (ur.), Recent Studies on Past and Present: New Sources, New Methods or a New Public?, Bucharest, 64-66.

Bârcă 2013 = Vitalie Bârcă, Nomads of the steppes on the Danube frontier of the Roman Empire in the $1^{\text {st }}$ century CE. Historical sketch and chronological remarks, Dacia, 67, 99-125.

Bârcă 2014 = Vitalie Bârcă, Olbia, Tyras, the Roman Empire and the Sarmatians in the Second Half of the $1^{\text {st }}$ - Early $2^{\text {nd }}$ Century AD; u: Costin Croitoru, Valeriu Sîrbu (ur.), Ancient linear fortifications on the lower Danube, Proceedings of the National Colloquium "Ancient Linear Fortifications on the Left Bank of the Lower Danube" (Brăila, 14-16 june 2013), Cluj-Napoca, 167-190.

Bennett 1997 = Julian Bennett, Trajan: Optimus Princeps, a Life and Times, London. Birley $2000=$ Anthony R. Birley, Hadrian to the Antonines, Cambridge Ancient History, $2^{\text {nd }}$ edition, vol. XI, The High Empire, A. D. 70-192, Cambridge, 132-194.

Forlati Tamaro 19476 = Bruna Forlati Tamaro, Inscriptiones Italiae, 10, 1, Pola et Nesactium, Roma.

Genito 1988 = Bruno Genito, The Archaeological Cultures of the Sarmatians with a Preliminary Note on the Trial Trenches at Gyoma 133: A Sarmatian Settlement in South-Eastern Hungary (Campaign 1985), Annali, Istituto Orientale di Napoli, 48, 81-126. 
Harmatta 1970 = János Harmatta, Studies in the History and Langauge of the Sarmatians, Acta Universitatis de Attila Jozsef nominatae, Acta Antiqua et Archaeologica, 13, Szeged.

Karavas 2001 = John Karavas, The Evolution of Roman Frontier Defence Systems and Fortifications in the Lower Danube Provinces in the First and Second Centuries AD, PhD Thesis, Durham.

Milićević Bradač 2004 = Marina Milićević Bradač, Stara Grčka. Grci na Crnom moru, Zagreb.

Mócsy 1974 = András Mócsy, Pannonia and Upper Moesia. A History of the Middle Danube Provinces of the Roman Empire, London and Boston.

Opreanu 2011 = Coriolan Horațiu Opreanu, The Barbarians and Roman Dacia. War, Trade and Cultural Interaction, u: Eric C. De Sena, Halina Dobrzanska (ur.), The Roman Empire and Beyond: Archaeological and Historical Research on the Romans and Native Culture in Central Europe, BAR International Series 2236, Oxford.

Rostovtzeff 1931= Mikhail Rostovtzeff, Skythien un der Bosporus, I-II, Berlin 1931.

Ryle 1987 = Stephen F. Ryle, Rome and the Roxolani in Tacitus, Histories I, Hermathena, 143, 93-97.

Vaday 1977 = Andrea H. Vaday, Rasparaganus rex Roxolanorum, Mitteilungen des Archäologischen Instituts der Ungarischen Akademie der Wissenschaften, 7, 27-31.

Vernadsky 1959 = George Vernadsky, The Origins of Russia, Oxford 1959.

Weisshäupl 1901 = R. Weisshäupl, Zur Topographie des alten Pola, Jahreshefte des österreichischen archäologischen Instituts in Wien, I, 4, Beibl., 169-208.

Wilkes 1983 = John J. Wilkes, Romans, Dacians and Sarmatians in the First and Early Second Centuries, u: Brian Hartley, John Wacher (ur.), Rome and her Northern Provinces. Papers Presented to Shepard Frere, Oxford, 255-289.

Wilkes 1996 = John J. Wilkes, The Danubian and Balkan Provinces, Cambridge Ancient History, $2^{\text {nd }}$ ed., vol. X, The Augustan Empire, 43 B. C. - A. D. 69, Cambridge, 545-585.

Wilkes $2000=$ John J. Wilkes, The Danube Provinces, Cambridge Ancient History, $2^{\text {nd }}$ ed., vol. XI, The High Empire, A. D. 70-192, Cambridge, 577-603. 
Summary

\section{The Pula Exile of Rasparaganus, King of the Sarmatian Roxolani}

Inscriptions on Two Sarcophagi at the Archaeological Museum of Istria in Pula Mentioning the Sarmatian King Rasparaganus and his son Aelius Peregrinus:

1. P(ublio) Aelio Rasparagano / regi Roxo[la]noru[m] / [u(xor)] v(iva) [f(ecit)]

2. P(ublius) Aelius Peregrinus reg[is] / Sarmatarum Rasparagani / f(ilius) v(ivus) f(ecit) sibi et Attiae Q(uinti) f(iliae) Procillae, lib(ertis) l[iber]/tabusq(ue) posterisq(ue) eorum

The first inscription was discovered in the $17^{\text {th }}$ century. It had a tumultuous modern history: it was transferred to Koper, where it was seen by Theodor Mommsen, then moved to Trieste by Pietro Kandler and back to Pula in the 1920s. Today, it consists of seven fragments, with only the first and the second line of the inscription preserved. The second inscription is complete, though broken into four parts. It was found in the mid- $19^{\text {th }}$ century on the island of Uljanik in the port of Pula.

Kandler and Mommsen have recognized the Roxolan ethnic name and linked it to a brief mention in the Historia Augusta (Hadr. 6, 6-8): The writer of Hadrian's biography does not mention the name of the king, but according to the assumption of all modern historians who dealt with the Roxolani and the Sarmatians in the $1^{\text {st }}$ and the $2^{\text {nd }}$ centuries, the king in question is Rasparaganus. The Roxolani lived around the mouth of the Danube, and Trajan reconciled them by paying a certain amount of money.

Strabo says the Roxolani are the farthest of all known Scythians, that they live beyond the Boristenes River (Dnieper), that the Sarmatians around the Maeotis Lake (Azov Sea) live southwards of them, and that the countries to the north of the Roxolani are uninhabited due to the extreme cold (Strabo 2, 5, $7,13)$. Later he asserts $(7,3,17)$ that they are a part of a Sarmatian confederation that further includes the Jazyges, the Urgi and the Royal Scythians, that they are a nomadic people, and that they fought the Pontic King Mithridates VI Eupator, who came to assist Chersonesus in Crimea, adding details on their armament and way of life.

However, under the pressure of migrations from the east, parts of the Scythian (Sarmatian) confederation headed west during the $1^{\text {st }}$ century BC, so the Roxolani ended up between the Carpathians and the Danube, neighbours of the Thraco-Phrygian Dacians. As early as in the mid- $1^{\text {st }}$ century AD, they began to occasionally cross the Danube into Moesia; they were defeated in 69 AD by the Romans (Tac. Hist., 1, 79), but in 92 AD they destroyed the XXI legion. However, Trajan started the conquest of Dacia shortly afterwards, and the Roxolani, allied to the Dacians, were again defeated in 101-102 AD. They remained neutral in the second Dacian war, and the price of their neutrality might have been a stipendium (an annual tribute) promised by Trajan.

The Sarmatians (Jazyges) and the Roxolani rebelled in 117 AD, shortly after the news of Emperor Trajan's death was received. Hadrian sent an army against them, and he himself arrived in $118 \mathrm{AD}$ (HA 6, 6-8). The reason for the unrest was a reduction in the stipendium that Trajan had agreed to pay them 
in exchange for peace. Hadrian personally negotiated with them, considered their complaint, and made peace with them again. The terms of the agreement are unknown (the text of HA does not explicitly say that Hadrian reinstated the stipendium). However, some authors assume that Hadrian even agreed to withdraw the Roman army from the eastern slopes of the Carpathians and the left bank of the Danube. This is not supported by written sources, only by archaeological data; hence, the assumption should be made with a reservation. The withdrawal from the slopes of the Carpathians would significantly weaken the security of Dacia, and the border with the legionary camps on the Danube was established anyway. According to one possible interpretation, the agreement had the added benefit for a Roxolan "king", who would allegedly have been declared amicus populi Romani and granted the Roman citizenship. It is generally accepted that it was Rasparaganus from the Pula inscriptions.

It is not known for how long the treaty had remained in place, but the fact that Rasparaganus's name is found on two tombstones in Pula might indicate that at some point after the year $118 \mathrm{AD}$, the king was forced to resign, and that he sheltered in the territory of the Roman state. As a Roman citizen (if he had indeed received the Roman citizenship by that time), he was entitled to it, although in every respect he was a refugee, relocated into another culture. Romanian scientists speculate that this possibly occurred at the beginning of the reign of Emperor Antoninus Pius (138 AD), when the scenario of 118 AD might have been repeated: to force the extension of the agreement, perhaps even at better terms, from the new emperor, the Roxolani rebelled again, but as Rasparaganus was the guarantor of the existing agreement, he was expelled from their community. We are closer to thinking that this happened soon after 118 AD. There are other, yet not many examples of similar situations in the history of the Empire: The Suebian King Marobodus was resettled by Tiberius in Ravenna, Catualdus soon after in Forum Julium (Frejus, Tac. 2, 62-63), but no mention of citizenship has been made. Somewhat differently, Claudius offered refuge to the Suevian Vanius, but he remained with his clients in Pannonia, near the border (Tac. 12, 30).

If Hadrian had granted Rasparaganus citizenship, he must have performed his royal duty in the interest of the Roman politics, which always closely monitored the relations between the peoples who lived in the neighbourhood, as it undoubtedly affected the security of the border area. Nevertheless, his departure must have pleased both the Roxolani and the Jazyges, as there was no dramatic news of conflicts in the following decades. We believe that it was only after he had left his countrymen that he was granted the Roman citizenship, and that he settled in Pula with only the most necessary entourage, perhaps his wife and a few servants. His son does not carry a Roxolan cognomen, but is a Peregrinus, which, as a general noun, is a designation of a person who is free, but has no citizenship. However, his nomen gentile (as well as his father's) clearly indicates that they were both Roman citizens, and it should probably be considered that it indeed was Hadrian himself who had allowed the grant.

Peregrinus may have been born after his father had already obtained citizenship, probably in Pula (we cannot however be certain), as the father did not give him a traditional Roxolan cognomen, but a general noun denoting a foreigner. The inscription does not mention any descendants, but the grave 
site was provided for all "their freedmen, the freedwomen and their descendants". In addition to the fact that the Rasparaganus case outlines the Roman approach, a pattern of securing and maintaining peace in the border provinces, the scarce information we dispose of about his son certainly contribute to understanding the economic and civic success of an individual, the son of a foreigner. The fate of Rasparaganus and his son Peregrinus is an example illustrating both the horizontal and the vertical mobility of social structures and, ultimately, the openness of the Roman society and its adaptability to conditions that had naturally changed in the course of the centuries of the Empire.

Keywords: ancient Istria; ancient Pula; Roxolani; Rasparaganus. 